\title{
CYBERLOAFING: PERANAN CONSCIENTIOUSNESS TERHADAP PEMALASAN SIBER PADA KARYAWAN
}

\section{CYBERLOAFING: THE ROLE OF CONSCIENTIOUSNESS OF CYBERLOAFING FOR EMPLOYEES}

\author{
Oleh: \\ Marissa ${ }^{1}$ \\ Achmad Irvan Dwi Putra ${ }^{2}$ \\ Sarinah $^{3}$
}

\begin{abstract}
Submitted: 27 Maret 2019

\section{Revision:}

29 Mei 2019

12 Juni 2019

Accepted:

21 Juni 2019

This study aims to determine the relationship between conscientiousness with cyberloafing. The hypothesis of this study stated that there is a negative correlation between conscientiousness with cyberloafing. The research subjects were 105 employeers who work in PT. C selected by purposive sampling. Data were obtained from a scale to measure conscientiousness and cyberloafing. The calculation was performed by means of testing requirements analysis (assumption) that consists of a test for normality and linearity test for relationships. The Analysis of the data was performed by Product Moment Correlation with SPSS 17 for Windows. The results of data analysis showed that the coefficient was -0.561 with $p 0.000$ ( $p$ $<0.05)$, means there is a negative correlation between conscientiousness with cyberloafing. These results indicate that the contribution given to cyberloafing by conscientiousness variable was $31,5 \%$.
\end{abstract}

Keywords: Conscientiousness; Cyberloafing; Employees.

\begin{abstract}
ABSTRAK
Penelitian ini bertujuan untuk mengetahui hubungan antara conscientiousness dan cyberloafing. Hipotesis yang diajukan dalam penelitian ini adalah ada hubungan negatif antara conscientiousness dengan cyberloafing. Subjek penelitian dalam penelitian ini adalah karyawan yang bekerja di PT. C sebanyak 105 orang yang dipilih dengan metode purposive sampling. Data diperoleh dari Skala conscientiousness dan cyberloafing. Perhitungan dilakukan dengan melalui uji prasyarat analisis (uji asumsi) yang terdiri dari uji normalitas dan uji linearitas hubungan. Analisis data yang digunakan adalah menggunakan korelasi Product Moment melalui bantuan SPSS 17 for Windows. Hasil analisis data menunjukan koefisien korelasi sebesar -0.561 dengan $\mathrm{p}$ sebesar $0,000(\mathrm{p}<0,05)$ yang menunjukkan adanya hubungan negatif antara conscientiousness dengan cyberloafing. Hasil penelitian ini menunjukkan bahwa sumbangan yang diberikan variabel conscientiousness terhadap cyberloafing adalah sebesar $31,5 \%$.
\end{abstract}

Kata kunci: Conscientiousness; Cyberloafing; Karyawan.

1Universitas Prima Indonesia, kuro115b@gmail.com

2Universitas Prima Indonesia, musisi059@gmail.com

${ }^{3}$ Universitas Prima Indonesia, sarinahlumbantoruan@gmail.com 


\section{PENDAHULUAN}

Internet adalah sistem komunikasi global yang menghubungkan jaringan pribadi, publik, akademik, bisnis, dan pemerintah menggunakan berbagai teknologi elektronik, nirkabel, dan optik yang luas dan terus berkembang. Internet juga memberikan kemudahan untuk mencari sumber informasi yang cepat sesuai dengan kebutuhan. Melalui internet, berbagai macam informasi yang disediakan dapat kita ketahui hanya dalam hitungan menit saja. Internet juga menjadi hal yang umum dengan kehidupan setiap kalangan masyarakat, khususnya di kalangan pekerja karyawan sesuai dengan data dari hasil survei yang dilakukan Asosiasi Penyelenggaraan Jasa Internet Indonesia (APJII), dimana penggunaan internet di tahun 2016 telah mencapai 132,7 juta orang atau sekitar 51,5 persen dari total penduduk di Indonesia dan 82,2 juta orang atau 62 persen didominasi oleh pekerja/ wiraswasta.

Perangkat-perangkat teknologi informasi (TI) yang terhubung ke internet, seperti komputer, tablet, dan smartphone memainkan peran utama dalam pengoperasian setiap organisasi. Perangkat-perangkat teknologi informasi (TI) yang terhubung ke internet tersebut sangat penting dalam membantu mengurangi biaya dalam bisnis, mempersingkat waktu siklus produksi dan layanan secara efisien. Lim (dalam Jiang, 2016) berpendapat keberadaan internet juga dapat membantu karyawan yang ada di perkantoran untuk menyelesaikan tugasnya dengan cepat, meningkatkan kreativitas, dan menghemat waktu dan biaya yang harus dikeluarkan seorang karyawan dan suatu perusahaan. Namun, kemudahan mengakses internet adalah pedang bermata dua, karena selain memberikan bantuan dan efisiensi bagi perusahaan, juga memberikan kesempatan kepada para karyawan melakukan penyalahgunaan fasilitas internet tersebut untuk tujuan hiburan dan hal-hal yang tidak berkaitan dengan pekerjaan sehingga perusahaan harus menyebarkan akses internet kepada karyawan dengan hati-hati karena potensi penyalahgunaan.

Menurut Lim (dalam Anandarajan \& Simmers, 2004), aktivitas penyalahgunaan fasilitas untuk mengakses internet yang disediakan oleh organisasi untuk kepentingan pribadi atau melakukan aktivitas yang tidak berhubungan dengan pekerjaan dan organisasi disebut cyberloafing. Sedangkan Robbins dan Judge (dalam Fuadiah, dkk., 2016) menyebutkan bahwa cyberloafing sendiri adalah tindakan individu yang menggunakan akses internet lembaganya selama jam kerja untuk kepentingan pribadi dan aktivitas-aktivitas internet lainnya yang tidak berhubungan dengan pekerjaan.

Tingginya perilaku pemalasan siber atau yang lebih dikenal dengan perilaku cyberloafing yang karyawan lakukan didapatkan dari hasil observasi yang peneliti lakukan terhadap komputer perusahaan beberapa karyawan di PT. C, dimana peneliti menemukan bahwa di komputer tersebut terinstal aplikasi untuk chatting yaitu WhatsApp dan Yahoo Messenger dan di beberapa ruang chat yang ada bukan hanya terdapat percakapan yang berhubungan dengan pekerjaan, tetapi terdapat pula percakapan pribadi karyawan dengan beberapa teman mereka. Lalu, dari hasil wawancara dengan beberapa karyawan di PT. C, dalam waktu 1 minggu, mereka mengatakan mampu mengakses internet pada saat jam kerja sebanyak 10 hingga 15 kali, sedangkan beberapa karyawan yang lain mengaku mengakses internet setiap selesai makan siang dan kebanyakan kegiatan yang dilakukan menggunakan internet tersebut adalah untuk mencari berita-berita yang sedang terjadi ataupun informasiinformasi tambahan untuk memenuhi keingintahuan mereka sendiri, mengakses media sosial maupun chatting online, atau browsing situs-situs di internet untuk menghilangkan rasa bosan di kantor. Mereka memiliki berbagai macam alasan untuk mengakses internet untuk kepentingan pribadi mereka dengan dalih pekerjaan yang ada masih sempat dikerjakan keesokan harinya. 
Cyberloafing dapat dipengaruhi oleh beberapa faktor, salah satu faktornya adalah trait conscientiousness. Jiang (2016), mengemukakan bahwa faktor kepribadian seperti kepribadian big five dan karakteristik demografis ditemukan secara signifikan dapat menjelaskan mengenai perilaku cyberloafing/ PIU. Secara spesifik, conscientiousness, kestabilan emosi/emotional stability, agreeableness, dan kejujuran/honesty memiliki hubungan yang negatif dengan perilaku cyberloafing/ PIU. Sebagai tambahan, Everton, Mastrangelo, dan Jolton (dalam Jiang, 2016), menemukan bahwa karyawan yang memiliki impulsivitas tinggi dan conscientiousness yang rendah akan lebih memungkinkan untuk melakukan perilaku cyberloafing.

Hal tersebut dibuktikan oleh Varghese dan Barber (2017) yang dalam penelitiannya menemukan bahwa cyberloafing dipengaruhi oleh personality trait melalui survei online pada Amazon Mechanical Turk (Mturk). Hasil yang mereka temukan adalah adanya hubungan negatif antara conscientiousness dengan cyberloafing yang menunjukkan semakin tinggi conscientiousness, maka akan semakin rendah cyberloafing yang dilakukan seseorang dan sebaliknya, semakin rendah conscientiousness, maka akan semakin tinggi perilaku cyberloafing yang dilakukan seseorang.

Personality trait atau sifat kepribadian, umumnya mengacu pada pola konsisten dalam cara individu berperilaku, merasa, atau berpikir (Pervin, dkk., 2015). Hasil dari beberapa studi yang lain menunjukkan bahwa kepribadian dapat memprediksi perilaku dan juga performansi sesorang dalam konteks pekerjaan, yang salah satunya adalah dimensi kepribadian Big Five. Kepribadian Big Five adalah kategori lima sifat utama yang mencakup emosionalitas, aktivitas, dan faktor sosiabilitas. Adapun kelima dimensi dalam kepribadian dimensi kepribadian Big Five, yaitu: openness, conscientiousness, extraversion, agreebleness, dan neuroticism (Pervin, dkk., 2015).

Conscientiousness mengacu pada konstruk dari orang yang sangat termotivasi untuk mencapai tujuannya sesuai definisi Goldberg (dalam Raad, 2000) yang mendeskripsikan conscientiousness sebagai individu yang terorganisasi, sistematis, efisien, praktis, dan mantap untuk mencapai tujuannya. Sedangkan menurut Costa dan McCrae (dalam Pervin, dkk., 2015) conscientiousness pada dasarnya mendeskripsikan perilaku berorientasi tugas dan tujuan juga kontrol impuls yang dipersyaratkan secara sosial, artinya conscientiousness menilai tingkat organisasi, ketekunan, dan motivasi dalam berperilaku berarah tujuan. Sockett (dalam Raad, 2000) juga menyatakan conscientiousness adalah sifat dengan makna perilaku yang terus terang dan relevansi sosial dan individu yang eksplisit.

Penelitian terdahulu juga pernah dilakukan oleh Jia, dkk., (2013) terhadap karyawan melalui survei online pada Study Response yang hasilnya menunjukkan adanya hubungan negatif antara conscientiousness dengan cyberloafing. Individu dengan level conscientiousness yang tinggi memiliki upaya yang tinggi untuk bekerja secara sistematis dan konsisten. Sebaliknya, orang dengan level conscientiousness yang rendah akan merasa kurang berorientasi dan motivasi sehingga akan selalu menerima begitu saja apapun hasil pekerjaannya.

Dengan melihat permasalahan yang terjadi pada karyawan khususnya di PT. C, maka peneliti tertarik untuk meneliti hubungan antara conscientiousness dengan cyberloafing pada karyawan di PT. C dengan hipotesis yang dapat diajukan dalam penelitian ini yaitu "adanya hubungan negatif antara conscientiousness dengan cyberloafing". Artinya, semakin tinggi conscientiousness yang dimiliki seseorang, maka semakin rendah perilaku cyberloafing yang terjadi dikarenakan mereka berupaya untuk menyelesaikan tanggung jawab mereka dengan baik dan tepat waktu, juga melakukan sesuatu secara teratur dan efisien. Namun sebaliknya, semakin rendah conscientiousness yang dimiliki seseorang, dimana seseorang cenderung suka menunda-nunda menyelesaikan tanggung jawab mereka dan tidak bekerja secara teratur, maka semakin tinggi perilaku cyberloafing yang terjadi. 


\section{METODE PENELITIAN}

\section{Variabel Penelitian}

Variabel terikat dalam penelitian ini adalah cyberloafing. Cyberloafing adalah perilaku penggunaan teknologi internet dan penyia-nyiaan waktu dengan menjelajahi internet dengan tujuan personal atau tidak berkaitan dengan pekerjaan pada saat jam kerja, di mana perilaku yang dilakukan adalah penggunaan email dan internet secara umum.

Sedangkan variabel bebas adalah conscientiousness. Conscientiousness merupakan kombinasi antara sifat dan karakteristik seseorang yang teratur, terorganisir, sistematis, ringkas, efisien, disiplin, dapat diandalkan, bertanggung jawab, teliti, cermat, tepat, rajin, gigih, ulet, dan pekerja keras.

\section{Subjek Penelitian}

Populasi dalam penelitian ini adalah 150 orang karyawan di PT. C dan dengan salah satu teknik nonprobability sampling, yaitu purposive sampling dengan karakteristik karyawan yang sudah bekerja lebih dari 3 bulan di di PT. C dan mengetahui mengenai internet dan penggunaannya, maka terpilihlah subjek penelitian sebanyak 105 orang karyawan.

\section{Metode Pengumpulan Data}

Alat pengumpul data yang digunakan dalam penelitian ini adalah menggunakan metode skala berupa kuesioner dengan disesuaikan pada aspek atau indikator dari variabel. Skala yang digunakan dalam penelitian ini adalah Skala Likert. Skala Likert disajikan dalam bentuk pernyataan yang bersifat favourable dan unfavorable dengan empat alternatif jawaban untuk setiap butir pernyataan sehingga kemungkinan jawaban di tengah-tengah dapat dihindari.

Skala Cyberloafing diukur menggunakan indikator cyberloafing berdasarkan 3 pengukuran perilaku cyberloafing yang dikemukakan oleh Blau, Yang, dan Ward-Cook (2006), yaitu: browsing activities, emailing activities, dan interactive activities dengan nilai koefisien validitas bergerak dari nilai 0.243 hingga 0.741 dan nilai reliabilitas sebesar 0.926 . Sedangkan skala Conscientiousness disusun menurut aspek-aspek conscientiousness yang dikemukakan oleh Goldberg (dalam Ryckman, 2008), yaitu: organization, efficiency, dependability, precision, dan persistance dengan koefisien validitas bergerak dari nilai 0.249 hingga 0.723 dan nilai reliabilitas sebesar 0.944 .

\section{Teknik Analisis Data}

Hasil penelitian ini menggunakan teknik analisis data korelasi Pearson Product Moment dibantu dengan menggunakan program SPSS 17 for Windows.

\section{HASIL DAN PEMBAHASAN}

Uji normalitas dilakukan agar dapat mengetahui apakah setiap variabel penelitian telah berdistribusi secara normal atau tidak. Uji normalitas yang dilakukan terhadap variabel cyberloafing menggunakan uji Kolmogorov Smirnov diperoleh koefisien KS-Z $=0.756$ dengan sig sebesar 0.616 untuk uji 2 (dua) arah. Karena hipotesis yang diajukan dalam penelitian ini bersifat 1 (satu) arah, maka sig uji 1 (satu) arah dari variabel cyberloafing sebesar 0.308 ( $\mathrm{p}$ > 0.05), yang berarti bahwa data pada variabel cyberloafing memiliki sebaran atau terdistribusi normal. Sedangkan untuk uji normalitas pada variabel conscientiousness diperoleh koefisien $\mathrm{KS}-\mathrm{Z}=0.901$ dengan sig sebesar 0.392 untuk uji 2 (dua) arah. Karena hipotesis yang diajukan dalam penelitian ini bersifat 1 (satu) arah, maka sig 1 (satu) arah dari variabel conscientiousness sebesar 0.196 ( $\mathrm{p}>0.05$ ), yang berarti bahwa data pada variabel conscientiousness memiliki sebaran atau terdistribusi normal. 
Variabel conscientiousness dan variabel cyberloafing memiliki hubungan linear sesuai dengan hasil yang terlihat dari nilai sig sebesar 0.000 maka $\mathrm{p}<0.05$. Jadi, dapat disimpulkan bahwa kedua variabel, yaitu variabel conscientiousness dan variabel cyberloafing, memiliki hubungan linear dan telah memenuhi syarat untuk dilakukan analisis Pearson Product Moment Correlation.

Tabel 1.

Hasil Uji Hipotesis

\begin{tabular}{cccc}
\hline Analisis & Pearson Correlation & Sig & R Square \\
\hline $\begin{array}{c}\text { Conscientiousness dan } \\
\text { Cyberloafing }\end{array}$ & $-0.561 * *$ & 0.000 & 0.315 \\
$* *$ signifikansi pada taraf 0.01 (1-tailed) & &
\end{tabular}

Berdasarkan hasil analisis korelasi antara conscientiousness dengan cyberloafing pada tabel 1, diperoleh koefisien korelasi Pearson Product Moment sebesar -0.561 dengan sig sebesar $\mathrm{p}=0.000(\mathrm{p}<0.05)$. Hal ini menunjukkan bahwa adanya korelasi negatif yang signifikan antara conscientiousness dengan cyberloafing sehingga dikategorikan hubungan yang sedang (Sugiyono, 2007). Dari hasil perhitungan tersebut, maka hipotesis yang diajukan dalam penelitian ini menunjukkan hubungan negatif antara conscientiousness dengan cyberloafing pada karyawan PT. C diterima dan dapat dinyatakan bahwa ada hubungan negatif yang sedang dan signifikan antara conscientiousness dengan cyberloafing.

Tabel 2.

\section{Sumbangan Efektif}

\begin{tabular}{ccccc}
\hline Model & $\mathbf{R}$ & R Square & Adjusted $\boldsymbol{R}$ Square & $\begin{array}{c}\text { Std. Error of } \\
\text { Estimate }\end{array}$ \\
\hline $\mathbf{1}$ & -0.561 & 0.315 & 0.308 & 15.182 \\
\hline
\end{tabular}

Berdasarkan tabel 2diatas, dapat disimpulkan dalam penelitian ini diperoleh koefisien determinasi $\left(\mathrm{R}^{2}\right)$ sebesar 0.315. Berdasarkan hasil tersebut, dapat disimpulkan bahwa sumbangan 31.5 persen conscientiousness memengaruhi cyberloafing dan selebihnya sebesar 68.5 persen dipengaruhi oleh faktor-faktor lain yang tidak diteliti pada penelitian ini.

Tabel 3.

Perbandingan Data Mean Empirik dan Hipotetik

\begin{tabular}{ccc}
\hline \multirow{2}{*}{ Variabel } & \multicolumn{2}{c}{ Mean } \\
\cline { 2 - 3 } & Empirik & Hipotetik \\
\hline Cyberloafing & 94.8 & 95 \\
\hline Conscientiousness & 75.24 & 87.5 \\
\hline
\end{tabular}

Hasil analisis pada tabel 3 untuk data cyberloafing diperoleh mean empirik < mean hipotetik yaitu $94.80<95$ maka dapat disimpulkan bahwa cyberloafing pada subjek penelitian lebih rendah daripada populasi pada umumnya dan pada hasil analisis untuk data 
conscientiousness diperoleh mean empirik < mean hipotetik yaitu $75.24<87.5$ maka dapat disimpulkan bahwa conscientiousness pada subjek penelitian juga lebih rendah daripada populasi pada umumnya.

Tabel 4.

Kategorisasi Data

\begin{tabular}{ccc}
\hline & Cyberloafing & Conscientiousness \\
\hline $\begin{array}{c}\text { Kategori Rendah } \\
\text { (Persentase) }\end{array}$ & $14(13.33 \%)$ & $54(51.43 \%)$ \\
\hline $\begin{array}{c}\text { Kategori Sedang } \\
\text { (Persentase) }\end{array}$ & $72(68.57 \%)$ & $51(48.57 \%)$ \\
\hline $\begin{array}{c}\text { Kategori Tinggi } \\
\text { (Persentase) }\end{array}$ & $19(18.10 \%)$ & $0(0 \%)$ \\
\hline
\end{tabular}

Berdasarkan kategorisasi pada tabel 4, maka dapat dilihat bahwa terdapat 14 subjek (13.33 persen) yang memiliki cyberloafing rendah, terdapat 72 subjek (68.57 persen) yang memiliki cyberloafing sedang, dan terdapat 19 subjek (18.10 persen) yang memiliki cyberloafing tinggi. Sedangkan pada variabel conscientiousness, dapat dilihat bahwa terdapat 54 subjek (51.43 persen) yang memiliki conscientiousness rendah, terdapat 51 subjek (48.57 persen) yang memiliki conscientiousness sedang, dan tidak terdapat subjek (0 persen) yang memiliki conscientiousness tinggi.

Penelitian pada 105 subjek yang bekerja di PT. C diperoleh hasil bahwa ada hubungan negatif antara conscientiousness dengan cyberloafing dengan koefisien korelasi Pearson Product Moment sebesar $\mathrm{r}=-0.561$ yang berada pada rentang 0.4-0.599 sehingga dikategorikan memiliki hubungan yang sedang (Sugiyono, 2007) dan nilai $\mathrm{p}$ sebesar $0.000(\mathrm{p}<0.05)$ yang artinya semakin tinggi tingkat conscientiousness karyawan, maka semakin rendah tingkat cyberloafing karyawan, dan juga sebaliknya, semakin rendah tingkat conscientiousness karyawan, maka semakin tinggi tingkat cyberloafing karyawan. Hasil dari penelitian ini diperoleh koefisien determinasi $\left(\mathrm{R}^{2}\right)$ sebesar 0,315. Berdasarkan hasil tersebut, dapat disimpulkan bahwa 31,5 persen variabel conscientiousness mempengaruhi cyberloafing, dan selebihnya 68,5 persen dipengaruhi oleh faktor lain.

Hasil penelitian juga senada dengan penelitian terdahulu yang dilakukan oleh Fuadiah, dkk., (2016) terhadap 60 orang subjek di Fakultas Syariah dan Ekonomi Islam IAIN Antasari, yang menyatakan bahwa salah satu dimensi dalam kepribadian big five yang mempengaruhi cyberloafing adalah conscientiousness, dimana diketahui bahwa ada peranan negatif conscientiousness terhadap perilaku cyberloafing. Karyawan yang memiliki conscientiousness tinggi cenderung tetap fokus pada pencapaian tugas saat bekerja, karena mereka memiliki kebutuhan tinggi untuk mencapai kinerja tertentu, dorongan untuk berhasil, dan keinginan untuk mencapai tujuan yang mulia sehingga menghalangi individu untuk terlibat dalam perilaku menyimpang seperti cyberloafing (O’Neill, Hambley, \& Berkovich, 2014).

\section{KESIMPULAN}

Berdasarkan hasil penelitian yang telah dilakukan, maka hipotesis yang diajukan sebelumnya dalam penelitian ini, yaitu adanya hubungan negatif antara conscientiousness dengan cyberloafing dapat diterima dengan hasil korelasi Pearson Product Moment (r) sebesar -0.561 dengan $\mathrm{p}$ sebesar $0,000(\mathrm{p}<0,05)$ yang artinya semakin tinggi conscientiousness maka akan semakin rendah perilaku cyberloafing, dan sebaliknya, semakin rendah conscientiousness maka akan semakin tinggi perilaku cyberloafing. Hasil penelitian ini juga menunjukkan bahwa 
sumbangan yang diberikan variabel conscientiousness terhadap cyberloafing adalah sebesar 31,5 persen, selebihnya 68.5 persen dipengaruhi oleh faktor-faktor lain yang tidak diteliti.

\section{DAFTAR PUSTAKA}

Anandarajan, M. \& Simmers, C. A. (2004). Personal Web Usage in the Workplace: A Guide to Effective Human Resources Management. USA: Idea Group Inc.

Asosiasi Penyelenggara Jasa Internet Indonesia. (2016). Penetrasi dan Perilaku Pengguna Internet di Indonesia. Dinduh dari: https://apjii.or.id/content/read/39/264/SurveiInternet-APJII-2016 tanggal 30 Desember 2017

Azwar, S. (2013). Penyusunan Skala Psikologi. Yogyakarta: Pustaka Pelajar.

Blau, G., Yang, Y. \& Phd, Ward-Cook, K. (2006). Testing a measure of cyberloafing.Journal of Allied Health, 35(1), 9-17.

Feist, J. \& Feist, G. J. (2008). Theories of Personality (ed $7^{\text {th }}$ ). USA: The McGraw-Hill Companies, Inc.

Fuadiah, L., Anward, H. H. \& Eriyani, L. (2016). Peranan conscientiousness terhadap perilaku cyberloafing pada mahasiswa. Jurnal Ecopsy, 3(1), http://dx.doi.org/10.20527/ecopsy.v3i1.1942

Jia, H., Jia, R. \& Karau, S. (2013). Cyberloafing and Personality: The Impact of the Big Five Traits and Workplace Situational Factors. Journal of Leadership \& Organizational Studies, $X X(\mathrm{X}), 1-8$. https://doi.org/10.1177/1548051813488208

Jiang, H. (2016). Employee Personal Internet Usage in the Workplace. Jyväskylä: Jyväskylä University Printing House.

O’Neill, T. A., Hambley, L. A., \& Bercovich, A. (2014). Prediction of cyberslacking when employees are working away from the office. Computers in Human Behaviour, 34, 291298. https://doi.org/10.1016/j.chb.2014.02.015

Pervin, L. A., Cervone, D., \& John, O. P. (2015). Psikologi Kepribadian Teori \& Penelitian Edisi Kesembilan. Jakarta: Kencana Prenamedia Group.

Priyatno, D. (2011). Buku Saku Analisis Statistik Data SPSS. Yogyakarta: Gaya Media.

Raad, B. D. (2000). The Big Five Personality Factors The Psycholexical Approach to Personality $\left(E d 9^{\text {th }}\right)$. Germany: Hongrefe \& Huber Publishers.

Ryckman, R. M. (2008). Theories of Personality. USA: Thomson Wadsworth.

Sugiyono. (2007). Statistika Untuk Penelitian. Bandung: CV Alfabeta.

Varghese, L. \& Barber, L. K. (2017). A preliminary study exploring moderating effects of role stressors on the relationship between Big Five personality traits and workplace cyberloafing. Cyberpsychology: Journal of Pychosocial Research on Cyberspace, 11 (4), article 4. http://dx.doi.org/10.5817/CP2017-4-4 